\title{
Introduction
}

\section{TRADE AND REGULATORY AUTONOMY}

Globalisation is a fact and one can see its effects particularly well in trade. For almost seventy years, trade liberalisation, which can be defined for present purposes as 'a process introducing greater market openness and a competitive market environment' through legally binding obligations, ${ }^{1}$ has been a key element of foreign trade policy for almost all of the world's nations. Although some question the net gains from trade (and especially the redistributive effects), it is undisputable that political leaders have taken the trade liberalisation route. Since the 1940s, international cooperation has led to the global reduction of tariff barriers through subsequent negotiating rounds in the context of the General Agreement on Tariffs and Trade or GATT 1947. In 1994, the Uruguay Round of negotiations culminated in the establishment of the World Trade Organization (WTO). Moreover, in parallel with multilateralism, a wave of bi- and plurilateral trade agreements highlight the perceived importance of trade liberalisation at a time in which the WTO is facing one of the most difficult periods in its existence, exemplified by the gridlocked negotiations in the Doha Round. Although in an altered form, i.e. from multilateral to preferential, it is clear that trade liberalisation is

1 Markus Krajewski, National Regulation and Trade Liberalization in Services (Kluwer Law International 2003) 5. Liberalisation does not equal deregulation, which indicates the removing or reducing of regulation. Complying with liberalisation obligations and commitments does not necessarily require deregulation. See Aaditya Mattoo and Pierre Sauvé, 'Domestic Regulation and Trade in Services: Key Issues' in Aaditya Mattoo and Pierre Sauvé (eds), Domestic Regulation and Service Trade Liberalization (World Bank \& Oxford University Press 2003) 1-2. Liberalisation does however often need reregulation. See Federico Ortino, 'Services' in Simon Lester and Bryan Mercurio (eds), Bilateral and Regional Trade Agreements: Commentary and Analysis (Cambridge University Press 2009) 214; Aik Hoe Lim and Bart De Meester, 'Addressing the Domestic Regulation and Services Trade Interface: Reflections on the Way Ahead' in Aik Hoe Lim and Bart De Meester (eds), WTO Domestic Regulation and Services Trade (Cambridge University Press 2014) 333. 
still at the forefront of international trade policy. However, even fierce supporters of trade liberalisation must recognise that the impact of liberalisation goes beyond what are traditionally seen as trade concerns. Economic concerns, such as the protection of intellectual property rights or competition law, have emerged in trade contexts. The impact of trade liberalisation has also extended to other types of societal choices. This is the result of obligations ascertained under international trade law, which typically limit domestic regulators in the exercise of their regulatory autonomy. ${ }^{2}$

Regulatory autonomy ${ }^{3}$ concerns regulatory measures or regulation, i.e. 'measures that a government characterizes as an exercise of its authority to regulate its domestic affairs' ${ }^{4}$ Market failures in a wide sense are at the core of why regulators regulate. ${ }^{5}$ In that way, governments provide public goods, redistribute income, and shield and support preferred activities, whether economic or not. ${ }^{6}$ More practically, regulatory autonomy is equally valuable because states opt for differing regulatory

2 Sungjoon Cho, Free Markets and Social Regulation: A Reform Agenda of the Global Trading System (Kluwer Law International 2003) 1.

3 The concept 'regulatory autonomy' goes by many monikers, including domestic regulatory autonomy, national regulatory autonomy, policy autonomy, unconstrained policy choice, juridical space, trade policy space, policy space, political space, regulatory room for manoeuvre, regulatory jurisdictional allocation, manoeuvring space, regulatory space, domestic sovereignty, domestic political sovereignty and policy autonomy, and sovereignty. In the context of international trade - and with the exception of sovereignty, of which regulatory autonomy is only a part - these terms have been used in similar ways and to indicate parts of the same concept.

4 Robert E Hudec, 'GATT/WTO Constraints on National Regulation: Requiem for an "Aim and Effects" Test' (1998) 32 The International Lawyer 619.

5 Aaditya Mattoo and Pierre Sauvé, 'Domestic Regulation and Trade in Services: Looking Ahead' in Mattoo and Sauvé (eds), Domestic Regulation and Service Trade Liberalization 223. See, extensively, Krajewski, National Regulation and Trade Liberalization in Services 11-40; Panagiotis Delimatsis, International Trade in Services and Domestic Regulations: Necessity, Transparency and Regulatory Diversity (Oxford University Press 2008) 37-83; and Tinne Heremans, 'Why Regulate? An Overview of the Rationale and Purpose Behind Regulation' in Aik Hoe Lim and Bart De Meester (eds), WTO Domestic Regulation and Services Trade (Cambridge University Press 2014) 25-44.

6 Bernard M Hoekman and Patrick A Messerlin, 'Liberalising Trade in Services: Reciprocal Negotiations and Regulatory Reform' in Pierre Sauvé and Robert M Stern (eds), GATS 2000: New Directions in Services Trade Liberalization (Brookings Institution 2000) 489. 
goals and methods, and their population has different needs and habits. ${ }^{7}$ Regulatory autonomy also is the autonomy to regulate. The regulator should be competent to enact regulation and this competence should not be restricted. For present purposes, the relevant restrictions are those imposed on regulators by international trade law. Thus, regulatory autonomy is linked to the balance between on the one hand domestic preferences reflecting domestic needs fulfilling domestic regulatory purposes, and on the other hand the adverse trade effects of such regulations. Regulatory autonomy can be defined as: 'how much margin of appreciation is left to [...] domestic governments in crafting their own regulations while at the same time fulfilling their [international trade law] obligations'. 8

Scholarship has highlighted many aspects of the trading system which constrain regulatory autonomy. I discern five dimensions of the concept of constraints on regulatory autonomy in international trade law:

a. Regulatory autonomy is constrained by exogenous and endogenous factors. Exogenous factors include, for example, international law obligations and interpretations thereof or political decisions in trading partners. Endogenous factors include, for example, domestic political pressure or business decisions by domestic companies. Both types of factors determine the actual amount of regulatory autonomy, which is therefore in a constant state of flux. I focus solely on the constraints on regulatory autonomy from international trade law obligations.

b. Regulatory autonomy may be constrained in so far as a regulator aims to advance an economic interest, or a non-economic interest. This distinction, which lies at the core of much of the debate on regulatory autonomy, has important consequences for the shaping of the tension between regulatory autonomy and trade liberalisation. My wide approach covers both.

c. Exogenous constraints on regulatory autonomy may stem from three inextricable macro-level aspects of international trade law:

7 Kalypso Nicolaïdis and Joel P Trachtman, 'From Policed Regulation to Managed Recognition in GATS' in Pierre Sauvé and Robert M Stern (eds), GATS 2000: New Directions in Services Trade Liberalization (Brookings Institution 2000) 248.

8 Michael Ming Du, 'Domestic Regulatory Autonomy under the TBT Agreement: From Non-discrimination to Harmonization' (2007) 6 Chinese Journal of International Law 269, 274. Du also notes that the domestic government should be democratic. 
trade negotiations, trade rules, and the interpretation of trade rules by the relevant dispute settlement bodies. Considering the practical legal approach taken in this book (see below), I focus on existing trade rules and their interpretation.

d. Considering the trade rules and their interpretation in more detail, constraints on regulatory autonomy are to be analysed according to the way in which a trade law violation is usually established: (i) the measure under scrutiny must fall within the scope of the agreement; (ii) it must violate an obligation contained in the agreement; and (iii) it cannot be justified by an exception.

e. Finally, the extent of constraints on regulatory autonomy may be linked to the nature of a trade law obligation, for example whether the obligation is a non-discrimination obligation, a market access obligation, a transparency obligation or a recognition-based regime.

In the case of trade governance, the liberalisation of trade has led to a binding set of rules and obligations, undersigned by all WTO Members, or, in the case of preferential liberalisation, the signatory parties. As with all international obligations, this necessarily implies a loss of regulatory autonomy: by agreeing to be bound by certain obligations, a domestic regulator may no longer adopt regulations which violate these international obligations. A regulator will normally only agree to restrict its regulatory autonomy if this leads to acceptable quid pro quos, ${ }^{9}$ because trade liberalisation obligations lead to domestic adjustment problems that can only be solved by enacting measures which may incidentally restrict trade. ${ }^{10}$ A similar balance must be struck for all types of international cooperation. However, in the case of the WTO, an international organisation famous for its well-functioning and binding dispute settlement system, it must be stressed that other states may force compliance with these obligations by bringing disputes in an effective manner. ${ }^{11}$ Moreover, as noted, economic governance is characterised by the inherent conflictive nature of the interests at play - i.e. offensive trade interests

9 Michael J Trebilcock and Robert Howse, 'Trade Liberalization and Regulatory Diversity: Reconciling Competitive Markets with Competitive Politics' (1998) 6 European Journal of Law and Economics 5, 30.

10 Dani Rodrik, 'How to Save Globalization from its Cheerleaders' (2007) 1 Journal of International Trade and Diplomacy 1, 21.

11 Pascal Lamy, 'The Emergence of Collective Preferences in International Trade: Implications for Regulating Globalisation' (Collective Preferences and Global Governance: What Future for the Multilateral Trading System, Brussels, 15 September 2004) 6. 
versus defensive non-trade interests, whether economic or non-economic, which may coincide with protectionism. ${ }^{12}$ Hence, the balancing of competing rights, principles, values and interests becomes one of the most important challenges for WTO law. ${ }^{13}$ In other words, the need for a balance is inherent because trade rules by nature impinge on other policy areas, and because trade restriction is an 'inevitable corollary' of policies with non-trade objectives. ${ }^{14}$ Already in 1969, a prominent scholar described the tension between regulatory autonomy and trade as fundamental:

One of the most fundamental issues facing GATT and international trade is whether or not there is a desirable limit to 'free trade' beyond which the policies of free trade would impose too much uniformity on particular national social or political systems and too greatly restrict the individual freedom of particular nations to pursue goals of their own societies. ${ }^{15}$

The tension between regulatory autonomy and trade liberalisation has become increasingly complex in recent times. Globalisation and other powers have led to increased economic integration. Considering that more economic integration inevitably leads to a reduction in regulatory autonomy, ${ }^{16}$ the altered approach of the international trading system, moving from non-discrimination to forms of market integration, and the ever wider scope of what is considered 'trade-related' substantially complicate the puzzle regarding the tension between regulatory autonomy and trade liberalisation. ${ }^{17}$ When focusing merely on nondiscrimination and not market integration, the balance conundrum is focused on exposing protectionist intent in regulation. Protectionist

12 Ibid. Also see Mattoo and Sauvé, 'Domestic Regulation and Trade in Services: Key Issues' 1.

13 Mads Andenas and Stefan Zleptnig, 'Proportionality and Balancing in WTO Law: A Comparative Perspective' (2007) 20 Cambridge Review of International Affairs 71, 88-89.

14 Panagiotis Delimatsis, 'The Fragmentation of International Trade Law' (2011) 45 Journal of World Trade 87, 96.

15 John H Jackson, World Trade and the Law of GATT (Bobbs-Merrill 1969) 28-29.

16 Robert M Hamwey, Expanding National Policy Space for Development: Why the Multilateral Trading System Must Change (South Centre Trade-Related Agenda, Development and Equity (TRADE) Working Paper 25, 2005) 10, figure 4.

17 Henning Grosse Ruse-Khan, A Comparative Analysis of Policy Space in WTO Law (Max Planck Institute for Intellectual Property, Competition \& Tax Law Research Paper 08-02, 2008) 10-11. 
regulation can be said to frequently favour domestic economic actors from the perspective of competition. This is sometimes intended but may sometimes be a sincerely unwanted consequence. ${ }^{18}$ However, from a market integration approach, regulatory heterogeneity itself could be considered a serious barrier to trade. ${ }^{19}$ This leads to a delicate balance between international trade objectives, bound by legal obligations, and legitimate domestic regulatory claims. ${ }^{20}$

A legal approach to drawing this line has its limits:

in some ultimate sense the problem is unsolvable. Taken to their logical conclusion, either free trade or local autonomy could virtually eliminate the other, and negotiating a working border between the two depends as much on history, politics, and local terrain as on any overarching vision. No matter how a legal test is articulated, it cannot satisfactorily resolve the tensions between local autonomy and free trade in all conceivable cases. In the end, the law must have a certain irreducible messiness in dealing with such fundamental tensions. Messiness is not, however, the same as chaos. ${ }^{21}$

Being aware of these limitations, this book can only strive to unravel some chaos - of which there is plenty in the subject of this book: the regulation of trade in services.

\section{TRADE IN SERVICES AND REGULATORY AUTONOMY}

The issue of constrained regulatory autonomy is especially challenging in the case of trade in services. Whereas services are usually described as being intangible, invisible, perishable and not storable, in practice they are usually defined by a list of activities which are considered to be services. The WTO Secretariat identifies 12 main categories of services:

18 Daniel A Farber and Robert E Hudec, 'Free Trade and the Regulatory State: A GATT's-Eye View of the Dormant Commerce Clause' (1994) 47 Vanderbilt Law Review 1401, 1402-1403; Hudec, 'GATT/WTO Constraints on National Regulation: Requiem for an "Aim and Effects” Test' 619-620; Delimatsis, International Trade in Services and Domestic Regulations: Necessity, Transparency and Regulatory Diversity 70.

19 Cho, Free Markets and Social Regulation: A Reform Agenda of the Global Trading System 1.

20 Hudec, 'GATT/WTO Constraints on National Regulation: Requiem for an “Aim and Effects" Test' 619-620.

21 Farber and Hudec, 'Free Trade and the Regulatory State: A GATT's-Eye View of the Dormant Commerce Clause' 1438. 
business services; communication services; construction and related engineering services; distribution services; educational services; environmental services; financial services; health related and social services; tourism and travel related services; recreational, cultural and sporting services; transport services; and other services not elsewhere included. ${ }^{22}$ From this, it is clear that a wide and heterogeneous range of activities in very different areas of economic activity falls under the notion of 'services'. ${ }^{23}$ Considering this wide range of activities, the importance of services to the economy is clear. In 2010, services accounted for 70 per cent of the value added to the world GDP. In comparison, agriculture accounted for just over 3 per cent and industry for the remaining 27 per cent. ${ }^{24}$ In the case of the EU, services were estimated to compose 73 per cent of EU GDP in 2014. ${ }^{25}$ Among other things, services account for an important share of total foreign direct investment and provide a significant proportion of employment opportunities. ${ }^{26}$ Importantly, services are inputs into production, for instance by facilitating transactions through space or time (e.g. transport or telecommunications services), or by producing human capital (e.g. education or research and development services). ${ }^{27}$ The 'facilitating' role of services leads to productivity gains across all sectors. In turn, this has a positive impact upon growth in the whole economy. ${ }^{28}$ Growth in services sectors, whether through size or diversification, is said to be a reflection of and a precondition for economic growth. ${ }^{29}$

22 General Agreement on Tariffs and Trade, MTN.GNS/W/120, Services Sectoral Classification List (1991).

23 Joseph Francois and Bernard M Hoekman, 'Services Trade and Policy' (2010) 48 Journal of Economic Literature 642, 645.

24 World Bank, 'Services, etc., Value Added (\% of GDP)' (2015) <http://data. worldbank.org/indicator/NV.SRV.TETC.ZS/countries/1W?display=graph> accessed 2 August 2015.

25 Central Intelligence Agency, 'The World Factbook: European Union' (2015) <https://www.cia.gov/library/publications/the-world-factbook/geos/ee.html> accessed 6 August 2015.

26 Francois and Hoekman, 'Services Trade and Policy' 644.

27 Ibid 645 and the references there.

28 Bernard M Hoekman, Liberalizing Trade in Services: A Survey (World Bank Policy Research Working Paper 4030, 2006) 21-22 and the references there.

29 Bernard M Hoekman and Aaditya Mattoo, 'Services Trade and Growth' in Juan A Marchetti and Martin Roy (eds), Opening Markets for Trade in Services: Countries and Sectors in Bilateral and WTO Negotiations (Cambridge University Press 2008) 53. 
Regardless of its importance in the economy, services underperform when it comes to trade. Indeed, although trade made up 59.5 per cent of world GDP in $2013,{ }^{30}$ trade in services accounted for 12.4 per cent of world GDP in 2013 - or roughly 20 per cent of total trade. ${ }^{31}$ However, the emergence of global value chains - producing goods from raw materials to final products not in one place, but wherever the necessary skills are available at a competitive price and quality - highlighted the key role of efficient services sectors in contributing to goods exports. ${ }^{32}$ Transport, logistics, finance, communication, other business, and professional services are necessary prerequisites for global value chains. Consequently, services play a more important role in trade than previously suggested. ${ }^{33}$ Services content in exports is just over 50 per cent of gross exports in the EU, and 42 per cent on average for G20 countries. ${ }^{34}$ In other words, the direct and indirect value added to all exports by services accounts for 50 per cent of the total value of global trade in goods and services. ${ }^{35}$ According to forward-looking studies based on computable general equilibrium (CGE) models, further liberalisation of trade in services is likely to generate greater gains than those from goods liberalisation. ${ }^{36}$

A reason for the remaining discrepancy between the share of services in GDP and in trade, aside from the un-tradability of some services sectors and practical reasons such as proximity between the service supplier and the consumer, is that services liberalisation is highly

30 World Bank, 'Trade (\% of GDP)' (2015) <http://data.worldbank.org/ indicator/NE.TRD.GNFS.ZS/countries?display=graph> accessed 6 August 2015.

31 World Bank, 'Trade in Services (\% of GDP)' (2015) <http://data.world bank.org/indicator/BG.GSR.NFSV.GD.ZS/countries?display=graph> accessed 6 August 2015.

32 OECD, World Trade Organization and UNCTAD, Implications of Global Value Chains for Trade, Investment, Development and Jobs (Report prepared for the G-20 Leaders Summit Saint Petersburg (Russian Federation), 2013) 2, 6 and 11.

33 Ibid 16.

34 Ibid 11.

35 Francois and Hoekman, 'Services Trade and Policy' 643. 'Value added' is the value that is added by the processing of imported components into final products for export as opposed to measuring trade flows on the basis of the gross value of goods crossing the border'.

36 Hoekman and Mattoo, 'Services Trade and Growth' 21-22 and the references there. 
complex due to the breadth of the concept of services ${ }^{37}$ and the importance of indirectly trade-related regulation. ${ }^{38}$ Services are characterised by extensive regulation, to such an extent where it can be said that '[e]ach regulatory act of a national government increases, at least potentially, the fragmentation of the world economy and, in this manner, might negatively encroach on the efficient delivery of services'. ${ }^{39}$ Indeed, services disciplines are 'primarily concerned with how an economy is regulated' ${ }^{40}$ In order to achieve the economic potential of liberalising trade in services, regulators need to be sure that their regulatory autonomy will be preserved. This is linked to two issues for regulators. The first issue is the intrusiveness of obligations. For example, in some cases, the incremental benefit of going beyond non-discrimination is unlikely to justify the political cost of strictly disciplining nondiscriminatory measures. ${ }^{41}$ The second issue is the inherent incomprehensibility and uncertain implications of constraints on regulatory autonomy. ${ }^{42}$ In conclusion, the tension between regulatory autonomy and trade liberalisation is more complicated in the area of trade in services, as the chances of stepping on the ground of trade obligations are substantial and potential conflicts between trade rules and domestic regulatory measures may loom large.

Being aware of these difficulties, negotiators at the WTO and at the preferential level have created a complex legal framework to liberalise trade in services. First, there are multilateral and preferential rules, which

37 Rudolf Adlung and Martin Roy, Turning Hills into Mountains? Current Commitments under the GATS and Prospects for Change (World Trade Organization Economic Research and Statistics Division Staff Working Paper ERSD2005-01, 2005) 6.

38 Hoekman and Mattoo, 'Services Trade and Growth' 53.

39 Delimatsis, International Trade in Services and Domestic Regulations: Necessity, Transparency and Regulatory Diversity 70-71; Adlung and Roy, Turning Hills into Mountains? Current Commitments under the GATS and Prospects for Change 6.

40 Lim and De Meester, 'Addressing the Domestic Regulation and Services Trade Interface: Reflections on the Way Ahead' 347.

41 Aaditya Mattoo, 'Services in a Development Round: Three Goals and Three Proposals' (2005) 39 Journal of World Trade 1223, 1224 and 1229-1232.

42 Hoekman, Liberalizing Trade in Services: A Survey 40. Even the EU and the US, with traditionally large resources of trade law capacity and the most experience in WTO litigation, 'claimed to have been surprised by the full implications' of the regulation of trade in services at WTO level as interpreted in the case law, even if the amount of case law remains very small. Mattoo, 'Services in a Development Round: Three Goals and Three Proposals' 1224 and 1229-1232. To some extent, more case law may reduce such surprises. 
overlap. On 15 April 1994, the Uruguay Round of negotiations was completed and international trade in services became part of the regulatory framework of the multilateral trading system. Annex $1 \mathrm{~B}$ to the Marrakesh Agreement contained the innovative General Agreement on Trade in Services (GATS) and its Annexes. Building on principles developed in the context of trade in goods, GATS faced the challenge of creating new disciplines for a complex, heterogeneous and increasingly important aspect of most economies: trade in services. Its rules and disciplines had a large impact on the regulatory landscape, even twenty years after its inception. This is a remarkable feat considering the boom of trade in services as a result of the information technology revolution. These technological advancements and the growing economic importance of trade in services have nonetheless put GATS' rules and disciplines under strain, especially since the agreement has not been updated since its entry into force. The multilateral services regulatory framework is not limited to the GATS and its Annexes. It also includes the plurilateral Agreement on Government Procurement, GATS Protocols, a Reference Paper on telecommunications, an Understanding on financial services, a waiver allowing preferential treatment to services of least-developed countries, and several Ministerial Declarations and Decisions. Additionally, the scope of some key aspects of GATS is dependent on each Member's unique Schedule of specific commitments (Schedule), and Members have submitted their list of exemptions to the Most-FavouredNation (MFN) obligation.

Aside from multilateral disciplines, the regulatory framework of trade in services also consists of rules and obligations in various types of regional trade agreements (RTAs) and preferential trade agreements (PTAs). ${ }^{43}$ According to the WTO, RTAs are agreements (i) to liberalise or facilitate trade on a regional basis (though parties are not required to belong to the same geographical region); (ii) between two or more partners in a reciprocal way; (iii) leading to preferential treatment. In the multilateral trading system, every formal relation between two or more states can accordingly be considered 'regional'. ${ }^{44}$ Hence, in the context of the EU foreign trade policy, all trade agreements which fulfil these conditions are RTAs, although they may have different official qualifications. Consequently, in WTO parlance, all non-multilateral reciprocal

43 Bilateral investment treaties (BITs) also regulate certain trade in services. For delineation purposes, this book does not address the regulation of trade in services in BITs.

44 Ousseni Illy, L'OMC et le Régionalisme - Le Régionalisme Africain (Larcier 2012) 35 and 68-69. 
trade agreements are RTAs, whilst PTAs grant unilateral trade preferences. Both types of agreement can be either bilateral or plurilateral.

Since 1992, there has been a surge in the conclusion of RTAs. The WTO counted more than 350 RTAs in force in 2012. More recently, negotiations for so-called mega-RTAs have dominated trade news, as groupings of states look to conclude plurilateral trade agreements. More recent RTAs contain services chapters. Although architecturally there are two families of services chapters - and some hybrid or sui generis forms - both the GATS-style and NAFTA-style families are built on fundamental GATS principles. These disciplines can build on and extend GATS rules (so-called GATS+ or GATS-Plus obligations), ${ }^{45}$ build on and reduce GATS rules (referred to as GATS- or GATS-Minus), ${ }^{46}$ or contain obligations not in the current GATS mandate (denoted as GATS-X). ${ }^{47}$ As concerns specific commitments on market access sensu lato ${ }^{48}$ and national treatment, it seems that, generally speaking, RTAs go (significantly) further. ${ }^{49}$

Moreover, the rules themselves are complex. GATS is structurally complex, and its language 'is often awkward and it should come as no surprise that many of the disputes evolve around misunderstandings

45 See for use of these terms, for example, Martin Roy, Juan A Marchetti and Hoe Lim, 'Services Liberalization in the New Generation of Preferential Trade Agreements (PTAs): How Much Further than the GATS?' (2007) 6 World Trade Review 155.

46 Rudolf Adlung and Peter Morrison, 'Less than the GATS: "Negative Preferences" in Regional Services Agreements' (2010) 13 Journal of International Economic Law 1103, 1136-1138; Rudolf Adlung and Sébastien Miroudot, 'Poison in the Wine? Tracing GATS-Minus Commitments in Regional Trade Agreements' (2012) 46 Journal of World Trade 1045.

47 The term 'GATS-X' is adapted from Horn, Mavroidis and Sapir's term 'WTO-X'. Henrik Horn, Petros C Mavroidis and André Sapir, 'Beyond the WTO? An Anatomy of EU and US Preferential Trade Agreements' [2010] The World Economy 1565.

48 It should be noted that the term 'market access' has a more specific meaning in the context of trade in services: Article XVI GATS limits the meaning of the term to a closed list of six types of restrictions to market access, which is market access sensu stricto. In this book, the term 'market access' will be used sensu stricto, as in Article XVI GATS, unless explicitly noted.

49 See Juan A Marchetti and Martin Roy, 'Services Liberalization in the WTO and in PTAs' in Juan A Marchetti and Martin Roy (eds), Opening Markets for Trade in Services: Countries and Sectors in Bilateral and WTO Negotiations (Cambridge University Press 2008). 
regarding the ambit of specific provisions' ${ }^{50}$ The same goes for many equally intricate RTAs with GATS+, GATS- and GATS-X obligations. From a practical perspective, the distinction between goods and services is not always clear (an issue not discussed in this book), ${ }^{51}$ and neither are the modal differences of services commitments (analysed further below).

Thus, the law on trade in services is a patchwork of applicable obligations (which do not always apply to all covered services) and commitments (by which any country unilaterally decides which services it subjects to which obligations) found in several regulatory regimes, which attempt to mitigate concerns regarding regulatory autonomy. Therefore, a general approach to assessing regulatory autonomy inevitably distorts the truth as the full potential impact on regulatory autonomy will never materialise. No WTO Member (Member) has made full commitments in all services sectors, and preferential liberalisation of trade in services is equally limited. The existence of different regulatory regimes and the zealous use of the available flexibilities in each regime indicate the need for a delineated approach to assess the balance between regulatory autonomy and services liberalisation.

\section{A CASE STUDY APPROACH: THE EUROPEAN UNION AND THREE EU RTAs}

The complexity of the regulatory framework regarding trade in services and the use of flexibilities therein make it an overly ambitious, even impossible, task to assess its constraints on regulatory autonomy. For the purpose of an in-depth analysis of the impact of multilateral and preferential liberalisation of trade in services on regulatory autonomy, the multilateral and preferential levels must be integrated. This necessarily requires taking a case study approach. In the case of multilateral obligations, all flexibilities will be addressed from the point of view of a

50 Juan A Marchetti and Petros C Mavroidis, 'From Reluctant Participant to Key Player: EU and the Negotiation of the GATS' in Inge Govaere, Reinhard Quick and Marco Bronckers (eds), Trade and Competition Law in the EU and Beyond (Edward Elgar Publishing 2011) 95.

51 What matters is whether the measure affects trade in services. CanadaCertain Measures Concerning Periodicals WT/DS31/AB/R, AB report adopted 30 July 1997 17-20. On the differentiation between goods and services, see e.g. Joost Pauwelyn, 'Squaring Free Trade in Culture with Chinese Censorship: The WTO Appellate Body Report on China-Audiovisuals' (2010) 11 Melbourne Journal of International Law 119; Tania Voon, 'China and Cultural Products at the WTO’ (2010) 37 Legal Issues of Economic Integration 254. 
selected WTO Member, and, as concerns bi- or plurilateral agreements, some of that country's RTAs can be analysed. This approach has the benefit of allowing a comparative and cross-cutting analysis.

The selected case study is the European Union (EU). On the one hand, the EU is often considered to be overregulated and overprotective domestically. On the other hand, services make up almost three-quarters of the EU's GDP. Being one of the world's largest economic entities, the EU's services market is of undoubted importance. ${ }^{52}$ In 2012, the EU was by far the largest exporter and importer of trade in services. ${ }^{53}$ The liberalisation of trade in services is also considered a European offensive interest, exemplified by the fact that the EU is party to a substantial number of RTAs that regulate trade in services. Hence, it is more of a rule maker rather than a rule taker. Consequently, it may have been and may still be in the best position to foresee the impact of the liberalisation of trade in services on regulatory autonomy, and hence build in necessary safety valves, or to make the most of the available flexibilities. Moreover, the EU played a key role in the drafting stage of GATS: it has been said that ' $[\mathrm{t}]$ he EU's hand can be traced in all key provisions of the GATS'. ${ }^{54}$ Such deep involvement indicates that the EU's use of the flexibilities in GATS (and its RTAs) are likely to have been thoroughly deliberated and to have taken prior experiences into account. Therefore, it would seem that regulators in the EU stand to be substantially affected by constraints on their regulatory autonomy. Europeans are also used to dealing with multilevel governance and balancing of interests, ${ }^{55}$ and their implications for regulatory autonomy. Therefore, this book addresses the extent to which the EU's multilateral (through GATS) and preferential (through selected RTAs) liberalisation of international trade in services constrains regulatory autonomy through imposing legally binding obligations.

To conduct the proposed analysis, and for the same reasons that the case study of the EU is necessary, a selection of EU RTAs must be made. Of course, only RTAs for which the text was available when the research commenced (July 2014) could be selected. After mapping the services

52 Daniel Drezner, All Politics is Global: Explaining International Regulatory Regimes (Princeton University Press 2007) 32-33.

53 World Trade Organization, International Trade Statistics 2013 (2013) 27.

54 Juan A Marchetti and Petros C Mavroidis, 'The Genesis of the GATS (General Agreement on Trade in Services)' (2011) 22 European Journal of International Law 689, 716. Also see Marchetti and Mavroidis, 'From Reluctant Participant to Key Player: EU and the Negotiation of the GATS' 48-95.

55 Chad Damro, 'Market Power Europe' (2012) 19 Journal of European Public Policy 682, 688. 
commitments in all EU RTAs containing services chapters, ${ }^{56}$ the most promising case studies are recently concluded EU RTAs which are primarily designed to open up global markets to European businesses, and the 'new generation' Deep and Comprehensive Free Trade Agreements (DCFTAs) concluded with countries targeted by the eastern part of the European Neighbourhood Policy. Considering the crucial importance of treaty interpretation for the purposes of assessing constraints on regulatory autonomy from legal provisions on trade in services, the selection of EU RTA case studies should also take into account the various approaches to treaty interpretation enshrined in the agreements. There are three such approaches. First, some EU RTAs are to be interpreted based on customary rules of interpretation only. Second, some EU RTAs are to be interpreted based on customary rules of interpretation in so far as the interpreted provision is not identical to a WTO provision. If the interpreted provision is identical, its interpretation 'shall be consistent with relevant WTO [Dispute Settlement Body] interpretations'. Third, the interpretation of some EU RTAs 'shall take relevant WTO [Dispute Settlement Body] interpretation into account'. (The relevance of this distinction may nonetheless be limited, as below, in Chapter 1, it is argued that a rebuttable presumption of WTO-consistent interpretation applies to EU RTAs.) Based on these criteria, and following the order of the three available approaches to interpretation, the following agreements are selected as case studies for the analysis of constraints on regulatory autonomy from the preferential liberalisation of trade in services: (i) the EU-Colombia \& Peru RTA; ${ }^{57}$ (ii) the EU-Singapore RTA;58 and (iii) the EU-Georgia DCFTA. ${ }^{59}$ Interestingly, both Georgia and Singapore are examples of 'the few countries in the world that [have] chosen a radical

56 Bregt Natens and Jan Wouters, Mapping Services Liberalisation Commitments in European Union Regional Trade Agreements (Leuven Centre for Global Governance Studies Working Paper 116, 2013).

57 Trade Agreement between the European Union and its Member States, of the one part, and Colombia and Peru, of the other part (OJ L 354, 21.12.2012, p. 3). At the time of writing, the EU and Ecuador concluded negotiations on Ecuador joining the RTA.

58 The latest update on the EU-Singapore RTA states that 'The draft agreement needs now to be formally approved by the European Commission and then agreed upon by the Council of Ministers, and ratified by the European Parliament'. European Commission, Overview of FTA and Other Trade Negotiations (Updated 16 September 2015).

59 Association Agreement between the European Union and the European Atomic Energy Community and their Member States, of the one part, and Georgia, of the other part (OJ L 261, 30.08.2014, p. 4). 
unilateral free trade opening of [their] economy to the whole of the world'. ${ }^{60}$ Consequently, both Georgia and Singapore can be expected to have had a 'constraining' impact on the negotiations, as they would have been looking for relatively unfettered liberalisation. ${ }^{61}$

As a matter of delineation, two important limitations of this book must be set forth. The first limitation is one ratione materiae. Aside from limiting the research to a case study of the EU and the three selected EU RTAs, the regulation of trade in services in the selected RTAs cannot be addressed in its totality. First, the investment or procurement chapters of the EU RTAs, which have an impact on trade in services as they also cover a certain form of supply of services, are not addressed. Second, EU RTAs often include sector-specific regulation of services, which do not have corresponding GATS obligations and would lead us too far afield. Third, several general obligations in the EU RTAs also apply to services. Whilst these are addressed where related to GATS obligations (e.g. in the case of current and capital transactions), they are not discussed when unrelated to GATS obligations.

The second limitation is that the methodology adopted to address the research problem is a comparative legal analysis of the constraints on regulatory autonomy from the multilateral liberalisation of trade in services, as compared with the preferential liberalisation. However, in the words of a prominent scholar of regulatory autonomy:

Sixty years of GATT/WTO dispute settlement history told us that the balancing line between trade liberalization and domestic regulatory autonomy has been drawn, erased and redrawn in the light of the specific facts of the case at hand and the prevailing sensitivities of the time. ${ }^{62}$

Therefore, the comparative legal analysis should be practical and based on the law as it stands. Where guidance from dispute settlement is available, case law serves as the basis of the present analysis. This is because two objectives of dispute settlement, as enshrined in Article 3.2

60 Michael Emerson, Countdown to the Vilnius Summit: The EU's Trade Relations with Moldova and the South Caucasus (The EU's Trade Relations with Moldova and the South Caucasus EXPO/B/FWC/2009-01/Lot 7/39, 2014) 13.

61 See as concerns Georgia, Patrick A Messerlin et al., An Appraisal of the EU's Trade Policy Towards its Eastern Neighbours: The Case of Georgia (SciencesPo and Center for European Policy Studies, 2011) 17.

62 Michael Ming Du, 'Has the WTO Appellate Body Pushed the Limits of Global Governance in the China-Publications Case? A Reply to Julia Ya Qin' (2012) 11 Chinese Journal of International Law 227, 231. 
of the Dispute Settlement Understanding (DSU) are securing predictability and security, and the filling of gaps and resolution of ambiguities in treaty text. ${ }^{63}$ Moreover, it is a goal of dispute settlement to provide a 'reasoned analysis of important policy implications of the rule application, so as to shed light on complex issues and dilemmas requiring a balancing approach' ${ }^{64}$ Undeniably, this applies to the balancing of regulatory autonomy and trade liberalisation. If no guidance from dispute settlement is available, an interpretation of the law must be based on treaty interpretation to devise the Members' common intention, rather than aiming for a perfect legal system. ${ }^{65}$ This requires some pragmatism, but that is a necessary corollary of the constructive ambiguity that led to the adoption of any treaty. ${ }^{6}$

\section{SUMMARY AND OUTLINE OF THE BOOK}

Trade in services is economically crucial, and will be more so when the share of trade in services in global trade rises to live up partially to its weight in GDP. Because the broad scope of activities considered as services includes heavily regulated economic activities that are not usually considered as related to trade, balancing trade liberalisation in services with regulatory autonomy is even more difficult than is the case for trade in goods. The complex regulatory framework created by the multilateral and preferential liberalisation of trade in services creates a further layer of intricacy. It is the purpose of this book to assess the constraints on EU regulatory autonomy resulting from the multilateral and preferential liberalisation of trade in services. The analytical approach taken is an in-depth case study that analyses the EU's obligations regarding trade in services under GATS and under three EU RTAs (EU-Colombia \& Peru, EU-Singapore and EU-Georgia). Before assessing the structure of these agreements (Chapter 2), their scope (Chapter 3),

63 John H Jackson, Sovereignty, the WTO and Changing Fundamentals of International Law (Cambridge University Press 2006) 148.

64 Ibid 150.

65 Lode Van Den Hende, 'GATS Article XVI and National Regulatory Sovereignty: What Lessons to Draw from US-Gambling?' (2007) 20 Cambridge Review of International Affairs 93, 105. See United States - Measures Affecting the Cross-Border Supply of Gambling and Betting Services WT/DS285/AB/R, AB report adopted 20 April 2005 paras 159-160.

66 For GATS, see Mexico - Measures Affecting Telecommunications Services WT/DS204/R, Panel report adopted 2 April 2004 para. 7.3. 
the obligations therein (Chapters 4-7) and the exceptions to these obligations (Chapter 8), it is necessary to explicate the interpretational framework (Chapter 1) for this book's practical comparative legal analysis. 